\title{
Changes in the epidemiology of visceral leishmaniasis in Brazil from 2001 to 2014
}

\author{
Lisiane Lappe dos Reis ${ }^{[1]}$, Antônio Alcirley da Silva Balieiro[ ${ }^{[1]}$, Fernanda Rodrigues Fonseca ${ }^{[1]}$ \\ and Maria Jacirema Ferreira Gonçalves ${ }^{[1],[2]}$
}

[1]. Instituto Leônidas e Maria Deane, Fundação Oswaldo Cruz, Manaus, AM, Brasil. [2]. Escola de Enfermagem de Manaus, Universidade Federal do Amazonas, Manaus, AM, Brasil.

\begin{abstract}
Introduction: Visceral leishmaniasis (VL) is a neglected disease, with territorial expansion and regional differences in Brazil that require explanation. This study aimed to describe changes in the epidemiology of VL in Brazil from 2001 to 2014. Methods: The incidence rates, sociodemographic and clinical data, and case evolution were subgrouped from 2001 to 2006 and from 2007 to 2014 and presented descriptively. Spatial distribution of disease incidence rates and changes in the spatial and temporal pattern were examined. Results: In total, 47,859 VL cases were reported in Brazil between 2001 and 2014, with predominance in the Northeast macroregion (55\%), though the incidence rate in this region declined between the two study periods. The State of Tocantins had the highest crude rate (26.2/100,000 inhabitants), which was responsible for VL increasing in the North macroregion. VL predominated in the urban zone (70\%), in children under 4 years $(34 \%)$; however, an increase in the incidence of VL in adults older than 40 years was identified, with $12.3 \%$ and $31 \%$ in the first and second period, respectively. The mapping of crude rates and autochthonous canine cases showed territorial expansion. The temporal distribution of VL was consistent in Brazil in general, with no pattern observed, but regional differences were found. Conclusions: The incidence of VL is increasing in Brazil. In addition to the State of Tocantins, which had the highest rate, new outbreaks of VL have occurred in the South macroregion of Brazil with small decreases identified in the incidence rate in the Northeast.
\end{abstract}

Keywords: Visceral leishmaniasis. Epidemiology. Epidemiologic profile. Spatial distribution. Information systems.

\section{INTRODUCTION}

Visceral leishmaniasis (VL) is classified as a Neglected Tropical Climate Disease (NTD) ${ }^{1}$, characterized by acute, subacute or chronic evolution, with more than $90 \%$ of untreated cases leading to death ${ }^{2}$. Among NTDs, VL placed third in terms of mortalities in Brazil from 2000 to 2011, causing more deaths than dengue or malaria ${ }^{3}$. VL has the highest years of lost life (YLL) due to premature death, as well as a high mortality rate among NTD, according to studies of global burden of diseases ${ }^{4,5}$.

Visceral leishmaniasis is present on five continents and more than $90 \%$ of cases occur in only 6 countries: India, Bangladesh, Sudan, South Sudan, Brazil, and Ethiopia ${ }^{6}$. In Brazil, VL is expanding territorially, with autochthonous cases in $25 \%$ of Brazilian municipalities in 21 of 26 states $^{7}$. VL is characterized by epidemiological changes, especially the urbanization of the disease, with human and canine cases reported in medium and large-sized cities and also expansion to other Brazilian macroregions ${ }^{8}$.

Corresponding author: Lisiane Lappe dos Reis.

e-mail: lisiane_reis@icloud.com

Received 5 July 2017

Accepted 5 October 2017
Prior studies have presented data regarding the epidemiology of VL, however the analyses were performed based on municipality ${ }^{9,10}$ or state ${ }^{11,12}$ and based on hospital data ${ }^{13,14}$. One study examined the mortality of VL in Brazil ${ }^{3}$ with another focused on the prediction of VL in Brazil ${ }^{15}$. This study analyzed the incidence rate of VL throughout Brazil, using the notifications sent to the Information System for Notifiable Diseases [Sistema de Informação de Agravos de Notificação (SINAN)] from 2001 to 2014. Considering that VL is an obligatory notifiable disease $^{16}$, these data represent all of the cases diagnosed in the country. Therefore, this large, comprehensive data set enabled a description of changes in the epidemiology of VL in Brazil, between the periods from 2001 to 2006 and from 2007 to 2014 .

\section{METHODS}

\section{Study population}

A descriptive study was undertaken on all new human cases of VL reported to the SINAN of the Brazilian Ministry of Health from 2001 to 2014, analyzing the municipality of patient residence. The database was subgrouped into two periods, 2001-2006 and 2007-2014, due to the changes in SINAN in the year 2007. No patient identification information of the subjects was provided during this study, so Human ethics 
approval was not required. Notifications in relation to relapses and transferred or unconfirmed VL cases were excluded. Estimates regarding population data were obtained from the Federal Audit Court (TCU), which were used to determine quotas of the Municipal Participation Fund (MPF); data was available from the Department of Information of the Unified Health System [Departamento de Informática do Sistema Único de Saúde (DATASUS)], according to the Brazilian Institute of Geography and Statistics [Instituto Brasileiro de Geografia e Estatística (IBGE) $]^{17}$.

\section{Analysis of regional incidence rates and spatial distribution}

The variables examined in this analysis were derived from the notification records ${ }^{18,19}$. The analysis was stratified by sex, based on age group, years of education, type of living area, macroregion, evolution of cases and clinical manifestations.

The incidence rates of VL were calculated for each state and region of Brazil by using the number of cases as the numerator and the number of people in the total population as the denominator and multiplying the outcome by 100,000 inhabitants. For each period studied (2001-2006 and 20072014), the population data was aggregated in the denominator. In this way, the numerator contains the sum of cases, and the denominator contains the sum of the population.

The crude incidence rates were calculated for the periods 2001-2006 and 2007-2014. Sociodemographic data, clinical data, and evolution of the cases were analyzed across the two time periods and presented by number and percentage.

The variation of the crude rate of VL per 100,000 inhabitants between the two time periods was calculated as follows: $\left(\left(\mathrm{x}_{1}-\mathrm{x}_{2}\right) /\right.$ $\left.\mathrm{x}_{2} * 100\right)$, where $\mathrm{x}_{1}=$ crude rate in VL in the period from 2007 to 2014 and $x_{2}=$ crude rate in VL in the period from 2001 to 2006. This rate variation was compared to the average VL disease incidence rate variation in Brazil. The value was multiplied by 100 and therefore represented the percentage variation of the rate. The decision to group and compare 6 and 8 years, 2001 to 2006 and 2007 to 2014, respectively, does not affect the result interpretation, as a previous test found interpolation in the confidence interval of the mean incidence rates between the groups.

The spatial distribution of VL was evaluated by mapping incidence rates per municipality and comparing distributions between the periods 2001-2006 and 2007-2014. For the mapping, QGIS $^{\circledR}$ software version 2.16 was used. The categorization of rates by mapping, as shown in Table 1, followed the cutoff suggested by the Pan American Health Organization ${ }^{20}$.

Data analysis was performed using Stata 9.0 software (StataCorp). Data preparation was conducted in a spreadsheet using Microsoft Excel 2010 (Microsoft Corp, Redmond, WA, USA).

\section{RESULTS}

From 2001 to 2014, 47,859 new cases of VL in Brazil were reported to SINAN, with an annual average of 3418.6 cases [standard deviation $(\mathrm{SD})=397.0$ ] and an average incidence rate of 1.8 per 100,000 inhabitants. The lowest rate was recorded in $2002(1.5 / 100,000$ inhabitants) and the highest in 2011
(2.0/100,000 inhabitants). There was an increase in the number of municipalities reporting VL cases (Figure 1), especially in the interior area of Brazil, which was previously an unregistered area. The percentage of municipalities reporting VL cases ranged from $11.7 \%$ in 2002 to $16.8 \%$ in 2014 (data not shown). Some states experienced a change in VL epidemiology and started to register vector or canine and human cases (Figure 1).

The number of VL cases in the Southern macroregion of Brazil increased; the region changed from a disease-free area in the first period (2001-2006) to an area with autochthonous canine and human VL cases in the second period (2007-2014). The Rondônia and Amapá States recorded autochthonous canine and vector cases, respectively. Only the Amazonas and Acre states did not have records of vector, canine, and human autochthonous cases. Cases reported in Amazonas were considered not to be of autochthonous origin. These data were added in the manuscript to reinforce the need for VL surveillance, but were not the object of primary data collection. However, a literature review was used to gather this information and to make a relationship with the findings in this study.

Aside from the Northeast region, all regions in Brazil showed an increase in the crude rate of VL in the second study period (2007-2014). The Northern macroregion had the highest rate of VL, due to cases in the state of Tocantins, which had the highest number of new cases in the country (Table 1). The highest rates in each macroregion were in the Mato Grosso do Sul, Minas Gerais, Tocantins, and Maranhão States, which are located in the CentralWest, Southeast, North and Northeast macroregions, respectively.

The mean percentage rate variation of VL in Brazil between the first and second period had increased by $1.38 \%$. Compared to the average percentage rate variation in Brazil, there were a number of states that experienced an increase of more than $100 \%$, and a few states that experienced a decrease (Figure 2).

The profile of VL cases is outlined in Table 2. This data showed a predominance in males, the under 9 year age group, less educated members of the population or people who were not yet in school, and those living in urban areas. While the rate of patients treated for VL decreased in the second period, there was an increase in the number of deaths, especially in males. A predominance of treatment abandonment was observed in males.

The incidence of visceral leishmaniasis coinfection with human immunodeficiency virus (VL-HIV) was highest in the second period (2007-2014), although there was missing data for this variable, as well as information on other clinical manifestations (Table 2).

\section{DISCUSSION}

This study identified geographical changes in the incidence of VL cases, which was characterized by an expansion to previously disease-free areas; mainly to the interior of Brazil (Figure 1), but there is also a strong urbanization component (Table 2). Despite the stability of the incidence rate in Brazil in general (Figure 2), the increase in the number of municipalities that commenced reporting cases of this important neglected disease deserves attention, as it confirms the territorial expansion. 


\section{TABLE 1}

Number of cases of visceral leishmaniasis and crude and standardized rates per 100,000 inhabitants, by state and macroregion of Brazil, in 2001-2006 and 2007-2014.

\begin{tabular}{|c|c|c|c|c|}
\hline \multirow{3}{*}{ States and macroregions } & \multicolumn{4}{|c|}{ Years } \\
\hline & \multicolumn{2}{|c|}{ 2001-2006 } & \multicolumn{2}{|c|}{ 2007-2014 } \\
\hline & crude rate & cases & crude rate & Cases \\
\hline Rondônia* & 0.02 & 2 & 0.1 & 12 \\
\hline Amazonas* & 0.03 & 5 & 0.04 & 11 \\
\hline Roraima & 2.5 & 56 & 2.4 & 85 \\
\hline Pará & 4.7 & 1,888 & 4.1 & 2,495 \\
\hline North & 3.7 & 3,097 & 4.3 & 5,491 \\
\hline Maranhão & 9.7 & 3,454 & 7.3 & 3,844 \\
\hline Piauí & 8.6 & 1,516 & 6.8 & 1,705 \\
\hline Ceará & 4.4 & 2,064 & 6.2 & 4,257 \\
\hline Rio Grande do Norte & 2.7 & 480 & 2.8 & 713 \\
\hline Bahia & 2.8 & 2,269 & 2.3 & 2,683 \\
\hline Northeast & 3.9 & 11,563 & 3.5 & 14,883 \\
\hline Minas Gerais & 2.1 & 2,360 & 2.3 & 3,612 \\
\hline Espírito Santo & 0.11 & 21 & 0.1 & 28 \\
\hline Rio de Janeiro & 0.02 & 21 & 0.03 & 33 \\
\hline São Paulo & 0.4 & 985 & 0.5 & 1,699 \\
\hline Southeast & 0.7 & 3,387 & 0.8 & 5,372 \\
\hline Paraná* & 0.024 & 15 & 0.019 & 17 \\
\hline Santa Catarina* & 0.006 & 2 & 0.014 & 7 \\
\hline Rio Grande do Sul & 0.003 & 2 & 0.02 & 19 \\
\hline South & 0.01 & 19 & 0.02 & 43 \\
\hline
\end{tabular}

Note: The crude rates, which are depicted in bold and italic, indicate high rates (23.05-46.44), while the lines in bold are considered averages (9.56-23.04). *No reported autochthonous human cases in the study period. The difference between reports and the total number of cases ( 47 cases) can be explained by missing data of the municipality.

The expansion over time (Figure 1), as shown by VL-free areas in the first period (2001-2006) that reported vector, canine, or human cases in the second period (2007-2014), can be explained by simple adaptation of sandflies to varying temperatures and to the peridomiciles ${ }^{21}$, migratory movement of people with VL-contaminated $\operatorname{dogs}^{22}$, and to locals at the borders who have reported the disease $\mathrm{e}^{23}$. Some states that were previously considered disease-free started to report the first autochthonous canine cases; for example Rondônia ${ }^{24,25}$ in 2010 and Paraná ${ }^{26}$ and Santa Catarina $^{27,28}$ in 2012. These areas require active epidemiologic surveillance, because canine cases precede the human cases $^{21}$.

The State of Amapá has had no reported human autochthonous cases to date, although it is located on the border with Pará, which has records of human VL cases dating back to $1934^{29}$ and is part of the Guianan Ecoregion Complex (GEC), with autochthonous human cases in Venezuela and Northern Brazil ${ }^{30}$. However, this state reported the presence of the sandfly Lutzomyia longipalpis in 2013 for the first time ${ }^{31}$, which increases the potential risk of the disease in humans at this site, as also pointed out in State of Rondonia $^{32}$. In the State of Rio Grande do Sul, vector and canine cases were identified in 2008, and the first autochthonous human case was identified in 2009 in the municipality of São Borja ${ }^{33}$, which probably originated in the provinces of Argentina that border this municipality 23,34 .

The changes in VL epidemiology are also reflected in the extensive urbanization of cities, as the disease is predominantly associated with urban areas (Table 2). Previously, VL was considered a rural disease, however in the early 1980s 


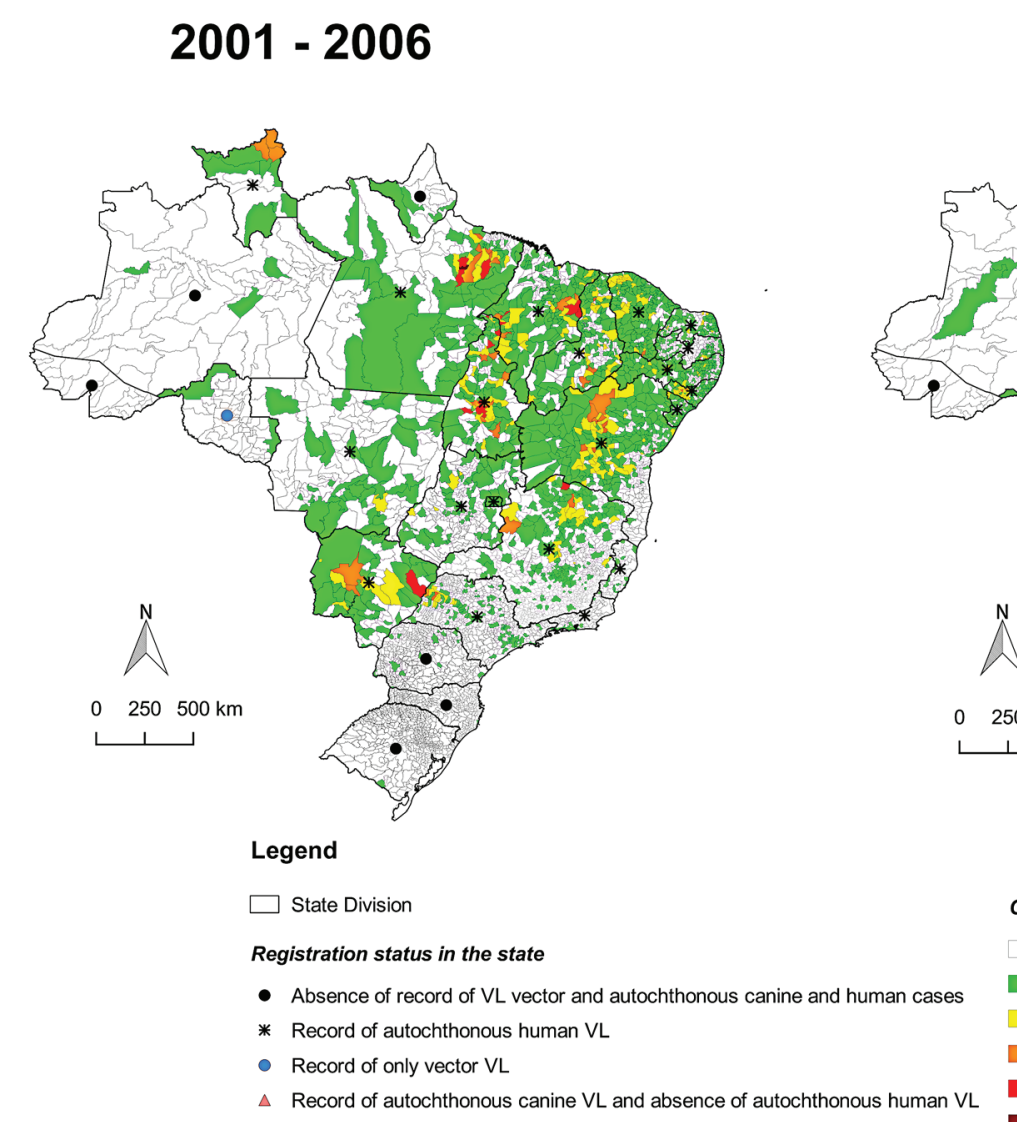

\section{7 - 2014}

(•) States without vector, autochthonous canine and human LV records in literature; ( 4 ) Rondônia: Silva, $2015^{25}$ Paraná: Dias et al, $2013^{26}$ Santa Catarina: Figueiredo et al, $2012^{27}$; (•) Amapá: Galardo et al, 201331 Rondônia: Gil et al, 2003'32; (*)States with records of autochthonous human cases in SINAN.

FIGURE 1 - Crude rate of new cases of visceral leishmaniasis per 100,000 inhabitants by municipality, in the periods 2001-2006 and 2007-2014. Source: SINAN, updated in September 2015. VL: visceral leishmaniasis; SINAN: Information System for Notifiable Diseases.

Cases per 100,000 inhabitants by municipality

No cases reported

0.01 -- 9.55 (Low)

9.55 -- 23.04 (Medium)

$23.04 \mid--46.44$ (High)

$46.44 \mid--96.35$ (Intense)

$>=96.35$ (Very Intense)

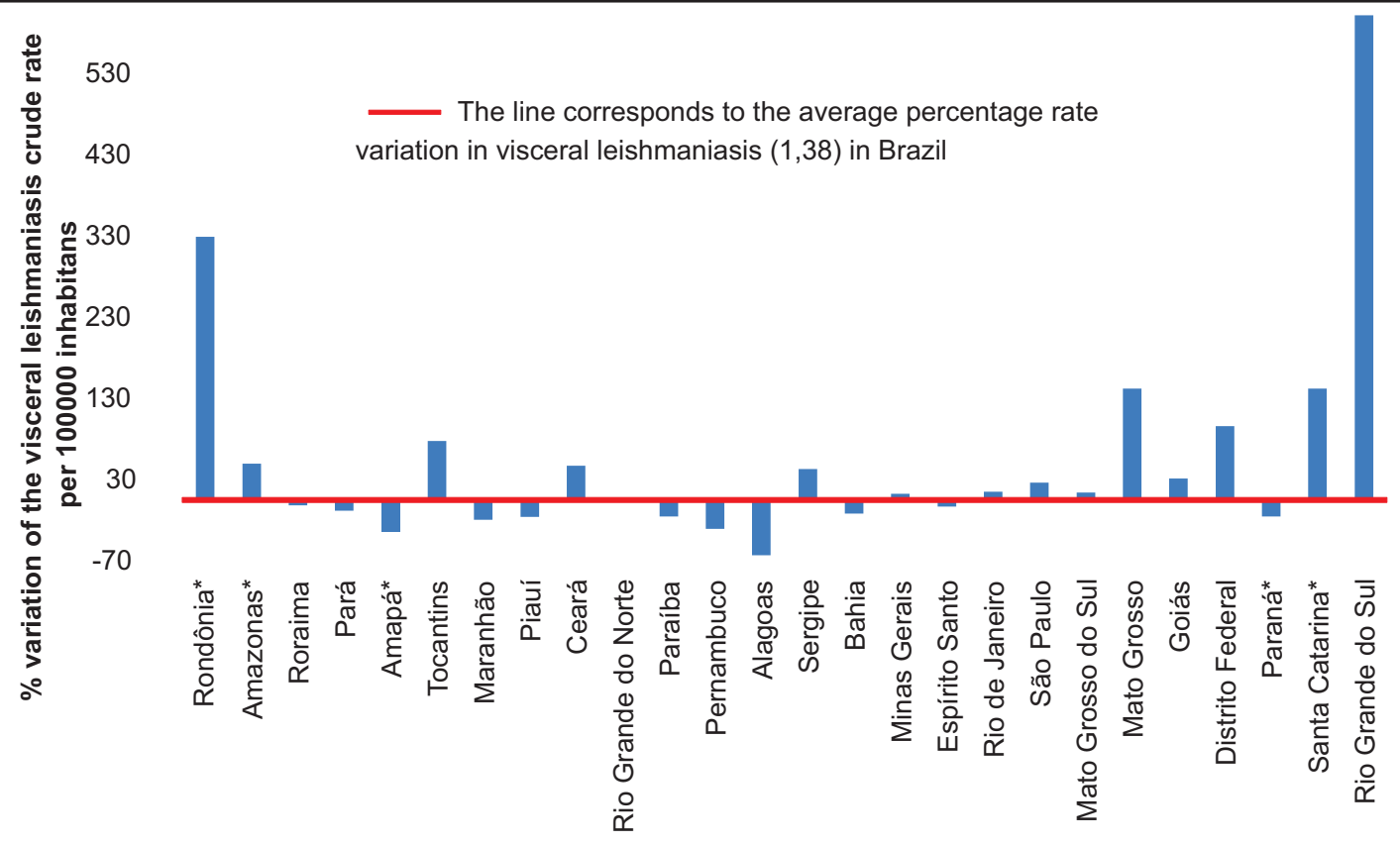

FIGURE 2 - Percentage variation of the visceral leishmaniasis crude rate per 100,000 inhabitants in the periods 2001-2006 and 2007-2014, compared to the average percentage variation (1.38) of Brazil as depicted by the red line. VL: visceral leishmaniasis; SINAN: Information System for Notifiable Diseases. *States with no reports of autochthonous human VL cases. The Acre State has not reported any human VL cases to SINAN. 
TABLE 2

Epidemiologic characteristics of visceral leishmaniasis cases in Brazil in 2001-2006 and 2007-2014.

\begin{tabular}{|c|c|c|c|c|c|c|c|c|c|c|c|c|}
\hline \multirow{2}{*}{ Characteristics } & \multicolumn{6}{|c|}{$2001-2006(n=19,496)$} & \multicolumn{6}{|c|}{$2007-2014(n=28,363)$} \\
\hline & \multicolumn{2}{|c|}{ male } & \multicolumn{2}{|c|}{ female } & \multicolumn{2}{|c|}{ total } & \multicolumn{2}{|c|}{ male } & \multicolumn{2}{|c|}{ female } & \multicolumn{2}{|c|}{ Total } \\
\hline $\begin{array}{c}\text { Years group } \\
0 \text { to } 4\end{array}$ & 3,517 & 50.3 & 3,477 & 49.7 & 6,994 & 35.9 & 4,697 & 50.9 & 4,522 & 49.1 & 9,219 & 32.5 \\
\hline 5 to 9 & 1,998 & 54.7 & 1,654 & 45.3 & 3,652 & 18.7 & 1,437 & 54.3 & 1,209 & 45.7 & 2,646 & 9.3 \\
\hline 10 to 19 & 1,679 & 59.6 & 1,138 & 40.4 & 2,817 & 14.4 & 1,596 & 63 & 938 & 37 & 2,534 & 8.9 \\
\hline 20 to 39 & 2,741 & 75.3 & 901 & 24.7 & 3,642 & 18.7 & 3,959 & 76.4 & 1,221 & 23.6 & 5,180 & 18.3 \\
\hline none & 665 & 71 & 272 & 29 & 937 & 4.8 & 504 & 73 & 186 & 27 & 690 & 2.4 \\
\hline 1 to 8 & 3,024 & 67.7 & 1,441 & 32.3 & 4,465 & 22.9 & 5,554 & 71.8 & 2,185 & 28.2 & 7,739 & 27.3 \\
\hline$\geq 9$ & 757 & 68.8 & 344 & 31.2 & 1,101 & 5.7 & 1,401 & 69.7 & 610 & 30.3 & 2,011 & 7.1 \\
\hline not apply or ignored & 7,255 & 55.8 & 5,738 & 44.2 & 12,993 & 66.6 & 10,350 & 57.7 & 7,573 & 42.3 & 17,923 & 63.2 \\
\hline \multicolumn{13}{|l|}{ Type living area } \\
\hline North & 1,827 & 58.5 & 1,297 & 41.5 & 3,124 & 16 & 3,246 & 59.3 & 2,232 & 40.7 & 5,478 & 19.3 \\
\hline Southeast & 2,036 & 61.4 & 1,280 & 38.6 & 3,316 & 17 & 3,353 & 62.9 & 1,979 & 37.1 & 5,332 & 18.8 \\
\hline Central-West & 983 & 61.8 & 608 & 38.2 & 1,591 & 8.2 & 1,779 & 65.4 & 943 & 34.6 & 2,722 & 9.6 \\
\hline South & 10 & 66.7 & 5 & 33.3 & 15 & 0.1 & 36 & 75 & 12 & 25 & 48 & 0.2 \\
\hline \multicolumn{13}{|l|}{ Evolution of cases } \\
\hline cure & 9,237 & 59.8 & 6,202 & 40.2 & 15,439 & 79.2 & 12,564 & 62.3 & 7,602 & 37.7 & 20,166 & 71.1 \\
\hline death & 870 & 61.8 & 539 & 38.3 & 1,409 & 7.2 & 1,541 & 66.9 & 763 & 33.1 & 2,304 & 8.1 \\
\hline ignored & 586 & 58.1 & 423 & 41.9 & 1,009 & 5.2 & - & - & - & - & - & - \\
\hline abandonment & - & - & - & - & - & - & 124 & 70.5 & 52 & 29.5 & 176 & 0.6 \\
\hline death by VL & - & - & - & - & - & - & 1,168 & 65.7 & 611 & 34.3 & 1,779 & 77.2 \\
\hline death by other causes & - & - & - & - & - & - & 373 & 71 & 152 & 29 & 525 & 22.8 \\
\hline \multicolumn{13}{|l|}{ Clinical manifestations } \\
\hline HIV coinfection & 261 & 71.7 & 103 & 28.3 & 364 & 1.9 & 1,178 & 76.7 & 357 & 23.3 & 1,535 & 5.4 \\
\hline
\end{tabular}

VL: visceral leishmaniasis; HIV: human immunodeficiency virus; -: absence of the variable on the report form. Note: The percentages of the variables by sex were calculated per row and the total percentages were calculated per column. The percentages of the variable death by VL and death by other causes were calculated from the total number of deaths, which included death by all causes, because the databases were not the same in the two periods. The number of evolution cases did not reach the total number of cases in both periods due to missing data. From 2007 to 2014, the percentage of evolution cases was not 100\%, because there were $7 \%$ of cases with the outcome transfer.

VL epidemics were recorded in an urban environment in Brazil ${ }^{8}$. The switch to urban areas is corroborated by the current study, in which approximately $70 \%$ of the cases were residents of urban areas. Although it is not possible to state that urban transmission is different from that in rural areas, some factors that might be involved in the process of urbanization of VL in Brazil are the environmental modifications caused by anthropic action, caused by migratory movements and nonplanned urban occupation together with poor sanitation ${ }^{35}$. In addition, the main vector of VL, the sandfly Lutzomyia longipalpis, has adapted to the peridomicile, especially in the presence of domestic animals such as $\operatorname{dogs}^{18}$.
The stability of the crude incidence rate in Brazil between the two time periods indicates that, even with an increase in the number of reported cases, there is no increase in the incidence rate, when population growth is considered. Therefore, the incidence of VL had increased, especially when analyzed per macroregion and state separately. In the 1990s, approximately $90 \%$ of the reported cases of VL were located in the Northeastern macroregion. With the spread of the disease to other regions, this situation has changed and a decrease in the number of VL cases has been observed in the Northeast ${ }^{21}$, whereas the North reported an increase in cases (Table 1). This expansion of the incidence 
rate is unrelated to the decision to subgroup the database into two time periods with an unequal number of years, considering that if an equal number of years were compared in the groups, a similar mean and interpolation in the confidence interval was found (data not shown). With respect to the spatial distribution, it is evident that municipalities that were previously free from the disease had changed their status.

Although the State of Maranhão reported the highest rate in the Northeast region (Table 1) and has a history of high incidence, overall there was a reduction in incidence reported. This may be due to the surveillance efforts in the Northeast, or to the emigration of the population ${ }^{36}$. For example, the State of Piauí previously had the highest incidence in the Northeast ${ }^{37}$ and now has a reported reduction, even though it is still the state with the second highest incidence in the Northeast. This expansion of the incidence in VL cases to other regions has occurred without a sufficient amount of time to organize health services for diagnoses, perform appropriate follow-up of the cases, and to train health professionals, who without the correct knowledge might recommend an inappropriate treatment regimen for patients with $\mathrm{VL}^{2,38}$.

The North of Tocantins State (Figure 1) had a remarkably high VL incidence rate when the geographical distribution was analyzed. This is mainly due to the extensive migratory flow of people from the Northeast, who live in poor housing conditions that lack urban infrastructure, sanitation and essential public services, such as garbage collection, health care and education ${ }^{39}$. These demographic and social problems are associated with the environmental impact caused by the deforestation in this state $^{40}$. This situation contributed to the epidemiologic situation identified in Tocantins, which deserves greater efforts to be made by the health services, both in the diagnosis and treatment of cases, as well as towards adequate surveillance services for this particular population.

Of all of the characteristics of VL, the predominance of the disease in males requires attention. The frequency of this disease in men increased with age (Table 2). Physiological factors are the most likely cause for the increased risk in males, indicating that from a certain age, sex hormones and the immune system in men result in a higher susceptibility to infection and disease ${ }^{41}$.

An increase of the disease in adults older than 40 years is noted in the second period of this study (Table 2), which can also be attributed to HIV coinfection ${ }^{42-44}$. From 2008, the number of adult patients exceeded the number of children with VL in Ceará, however, VL-HIV coinfection was predominant in the 20-39 year age group ${ }^{12}$. This phenomenon has also occurred in Southern Europe, North Africa, and Western and Central Asia. Since the beginning of HIV infections and increased use of immunosuppressants for transplantation and chemotherapy, approximately half of the VL cases in Europe are adults ${ }^{45}$. Therefore, HIV infection should also be considered in our study. Although a poorly performed routine HIV test was done, the data show an increase in the incidence of VL-HIV coinfection (Table 2).

The percentage of patients that were cured (Table 2) is lower than the number suggested by the Pan American Health Organization, which advocates that at least $95 \%$ of patients treated for VL are cured ${ }^{46}$. A study that was performed in the City of Bauru showed that $90.3 \%$ of the treated VL patients were cured ${ }^{9}$. The low number of patients that were cured may reflect the performance of the VL control program and the records in the information system. It is not known if the patients were cured or if there was a problem with the information system, since the evolution of the cases showed an increase of missing data; from $7 \%$ in the period $2001-2006$ to $13.2 \%$ in the period 2007-2014 (data not shown). This is a very serious problem as the information on the percentage of patients that were cured is critically important and related to the capacity of the health services to perform early diagnosis and to have disposal resources such as materials, laboratory, medicines and trained professionals to give the correct treatment to cases. This low percentage of patients that were cured indicates that it is necessary to evaluate the data record for completeness and quality ${ }^{47}$, as well as to have correct follow-up of the cases, in order to avoid abandoning of the treatment.

Failure to complete the evolution of the case, especially the cure information, is a concerning issue, because the absence of a cure contributes to unfavorable outcomes, such as abandonment and death. In addition to the increase in deaths in the second period, this may be an underestimate due to missing data. Although some patients survive even when they are not cured, they may have subclinical disease and with a return to illness in case of decreased immunity ${ }^{48}$, and may worsen if there is coinfection, especially with $\mathrm{HIV}^{49,50}$ or malaria, which has already been described in Brazil ${ }^{51}$ and Africa ${ }^{52}$.

VL should be suspected when a patient presents with fever and splenomegaly that might be associated with hepatomegaly ${ }^{18}$. These symptoms, which characterize the initial phase of the disease, were the most frequent in this study, together with weakness and weight loss. However, the latter are also observed in other infectious diseases ${ }^{18}$, which may cause confusion and delay the diagnosis of VL, thereby compromising the condition of the patient with malnutrition, bleeding and other bacterial infections that can lead to death. Therefore, there is a need for trained health professionals $\mathrm{s}^{38}$ and sensitizing health teams to recognize this important neglected disease in addition to the installation of adequate infrastructure for prompt laboratory diagnosis. In addition, health service structuring is needed in order to optimize epidemiologic surveillance, as well as vector control measures and inclusion of new methods of disease control in dogs.

\section{Conflict of interest}

The authors declare that there is no conflict of interest.

\section{REFERENCES}

1. World Health Organization (WHO). Neglected tropical diseases [Internet]. Geneve: WHO; 2017 [cited 2017 Apr 26]. Available from: www.who.int/neglected_diseases/diseases/en/

2. Pelissari DM, Cechinel MP, Sousa-Gomes ML, de Lima Jr FEF. Tratamento da leishmaniose visceral e leishmaniose tegumentar americana no Brasil. Epidemiol e Serviços Saúde. 2011;20(1): 107-10. 
3. Martins-Melo FR, Lima MDS, Ramos AN, Alencar CH, Heukelbach J. Mortality and case fatality due to visceral leishmaniasis in Brazil: A nationwide analysis of epidemiology, trends and spatial patterns. PLoS One. 2014;9(4):e93770.

4. Hotez PJ, Alvarado M, Basáñez MG, Bolliger I, Bourne R, Boussinesq M, et al. The Global burden of disease study 2010 : interpretation and implications for the neglected tropical diseases. PLoS Negl Trop Dis. 2014;8(7):e2865.

5. Lozano R, Naghavi M, Foreman K, Lim S, Shibuya K, Aboyans V, et al. Global and regional mortality from 235 causes of death for 20 age groups in 1990 and 2010: a systematic analysis for the Global Burden of Disease Study 2010. Lancet. 2012;380(9859):2095-128.

6. Alvar J, Vélez ID, Bern C, Herrero M, Desjeux P, Cano J, et al. Leishmaniasis worldwide and global estimates of its incidence. PLoS One. 2012;7(5):e35671.

7. Werneck GL. Visceral leishmaniasis in Brazil: Rationale and concerns related to reservoir control. Rev Saude Publica. 2014;48(5):851-6.

8. Werneck GL. Expansão geográfica da leishmaniose visceral no Brasil. Cad Saúde Pública. 2010;26(4):644-5.

9. Ortiz RC, Anversa L. Epidemiologia da leishmaniose visceral em Bauru, São Paulo, no período de 2004 a 2012: um estudo descritivo. Epidemiol e Serviços Saúde. 2015;24(1):97-104.

10. Botelho AC, Natal D. First epidemiological description of visceral leishmaniasis in Campo Grande, State of Mato Grosso do Sul. Rev Soc Bras Med Trop. 2009;42(5):503-8.

11. Oliveira AM, Vieira CP, Dibo MR, Guirado MM, Rodas LAC, Chiaravalloti-Neto F. Occurrence of Lutzomyia longipalpis and human and canine cases of visceral leishmaniasis and evaluation of their expansion in the Northwest region of the State of São Paulo, Brazil. Acta Trop. 2016;164(1):233-42.

12. Cavalcante IJM, Vale MR. Aspectos epidemiológicos da leishmaniose visceral (calazar) no Ceará no período de 2007 a 2011. Rev Bras Epidemiol. 2014;17(4):911-24.

13. Naufal Spir PR, Prestes-Carneiro LE, Fonseca ES, Dayse A, Giuffrida R, D'Andrea LAZ. Clinical characteristics and spatial distribution of visceral leishmaniasis in children in São Paulo state: an emerging focus of visceral leishmaniasis in Brazil. Pathog Glob Health. 2017;111(2):91-7.

14. Silveira LJD, Rocha TJM, Ribeiro SA, Pedrosa CMS. Historical series of patients with visceral leishmaniasis treated with meglumine antimoniate in a hospital for tropical diseases, Maceió-AL, Brazil. Rev Inst Med Trop Sao Paulo. 2015;57(1):33-8.

15. Karagiannis-Voules DA, Scholte RGC, Guimarães LH, Utzinger J, Vounatsou P. Bayesian Geostatistical Modeling of Leishmaniasis Incidence in Brazil. PLoS Neg1 Trop Dis. 2013;7(5):e2213.

16. Ministério da Saúde (MS). Portaria No 104, de 25 de janeiro de 2011 [Internet]. Brasília: MS; 2011 [citado em 4 de maio de 2017]. Disponível em: http://bvsms.saude.gov.br/bvs/saudelegis/gm/2011/ prt0104_25_01_2011.html

17. Ministério da Saúde (MS). Departamento de Informática do Sistema Único de Saúde (Datasus). População residente - estimativas para o TCU - Brasil. Brasília: MS; 2010 [citado em 3 de outubro de 2016]. Disponível em: http://www2.datasus.gov.br

18. Ministério da Saúde (MS). Departamento de vigilância em Saúde e Vigilância Epidemiológica. Manual de vigilância e controle da leishmaniose visceral. Brasília: MS; 2014. 120 p.

19. Ministério da Saúde (MS). Manual de Vigilância e Controle da Leishmaniose Visceral. Brasília: MS; 2006. 120 p.

20. Organização Pan-Americana da Saúde (OPAS). Leishmanioses - Informe Epidemiológico das Américas. Inf Leishmanioses.
2016, n 4:p. 1-7. Available from: http://iris.paho.org/xmlui/ bitstream/handle/123456789/34113/informe_leishmanioses_5_por. pdf? sequence $=1 \&$ is Allowed $=y$.

21. Ministério da Saúde (MS). Leishmaniose Visceral. Guia de Vigilância em Saúde. Brasília: MS; 2014. p. 547-68.

22. Furlan MBG. Epidemia de leishmaniose visceral no Município de Campo Grande-MS, 2002 a 2006. Epidemiol e Serviços Saúde. 2010;19(1):15-24.

23. Paula A, de Souza L, Teixeira MC. Estudo retrospectivo da epidemiologia da leishmaniose visceral no Rio Grande do Sul : revisão de literatura. Veterinária em Foco. 2014;11(2):112-8.

24. Aguiar DM, Oliveira TMFS, Cavalcante GT, Labruna MB, Camargo LMA, Machado RZ, et al. Seroprevalence of anti-Leishmania spp. antibodies in rural dogs from the city of Monte Negro, State of Rondônia, Brazil. Rev Bras Parasitol Veterinária. 2010;19(1):71-2.

25. José C, Mattos CB, Mattos RDG, Castanhêde LM, de Medeiros JF, Herman L, et al. III Encontro de Pós-Graduação e IX Encontro de Iniciação Científica - Universidade Camilo Castelo Branco. In: Vigilância epidemiológica da leishmaniose visceral canina após o primeiro caso autóctone em Rondônia. Rondônia; 2015. p. 367-8.

26. Dias RCF, Soccol VT, Bisseto Jr A, Pozzolo EM, Chiyo L, Freire RL. Occurrence of anti-Leishmania spp. antibodies in domiciled dogs from the city of Foz do Iguaçu, state of Paraná, Brazil. In: Fifth World Congress on Leishmaniasis, Paraná, Brazil. 2013. p. 826.

27. Figueiredo FB, Lima Jr FEF, Tomio JE, Indá FMC, Corrêa GLB, Madeira MF. Leishmaniose Visceral Canina : dois casos autóctones no município de Florianópolis, estado de Santa Catarina. Acta Sci Vet. 2012;40(1):4-7.

28. Steindel M, Menin A, Evangelista T, Stoco PH, Marlow MA, Fleith $\mathrm{RC}$, et al. Outbreak of autochthonous canine visceral leishmaniasis in Santa Catarina, Brazil. Pesqui Veterinária Bras. 2013;33(4):490-6.

29. Penna HA. Leishmaniose Visceral no Brasil. Bras Med. 1934;48:949-50.

30. Santos TV, Galardo AKR, Póvoa MM, Rangel EF. Increasing potential risk for american visceral leishmaniasis in Amapá, Brazil. Rev Soc Bras Med Trop. 2016;49(6):772-3.

31. Galardo AKR, Galardo CD, Santana AA, Mendes JCC, Souza FRA, Duarte JP, et al. Primeira ocorrência de Lutzomyia (Lutzomyia) longipalpis Lutz \&amp; Neiva, 1912 (Diptera: Psychodidae: Phlebotominae) no Estado do Amapá, Brasil. Biota Amaz. 2013;3(2):179-83.

32. Gil LHS, Basano SA, Souza AA, Silva MGS, Barata I, Ishikawa EA, et al. Recent observations on the sand fly (Diptera: Psychodidae) fauna of the State of Rondônia, Western Amazônia, Brazil: the importance of Psychdopygus davisi as a vector of zoonotic cutaneous leishmaniasis. Mem Inst Oswaldo Cruz. 2003;98(6): $751-5$.

33. Secretaria da Saúde do Estado do Rio Grande do Sul. Leishmaniose visceral humana - Caso Autóctone em Porto Alegre. Inf Vigilância em Saúde do Rio Grande do Sul. 2016;17;2(14):7.

34. Gould IT, Perner MS, Santini MS, Saavedra SB, Bezzi G, Maglianese MI, et al. Leishmaniasis visceral en la Argentina: notificación y situación vectorial (2006-2012). Medicina (B Aires). 2013;73(2):104-10.

35. Werneck GL. Forum: geographic spread and urbanization of visceral leishmaniasis in Brazil. Introduction. Cad Saude Publica. 2008;24(12):2937-40.

36. Henrique C, Costa N, Tapety CMM. Controle da leishmaniose visceral em meio urbano: estudo de intervenção randomizado fatorial. Rev Soc Bras Med Trop. 2007;40(4):415-9. 
37. Costa CHN, Pereira HF, Araújo MV. Epidemia de leishmaniose visceral no Estado do Piauí, Brasil, 1980-1986. Rev Saude Pública. 1990;24(5):361-72.

38. Alvarenga DG, Maria P, Escalda F, Sylvio A, Tereza M, Duenhas F. Leishmaniose visceral : estudo retrospectivo de fatores associados à letalidade. Rev Soc Bras Med Trop. 2010;43(2):194-7.

39. Antero R. Urbanização pela migração em Araguaína (TO). Caminhos Geogr. 2016;17(59):1-15.

40. Afonso MMS, Chaves SAM, Magalhães MAFM, Gracie R, Azevedo C, Carvalho BM, et al. Ecoepidemiology of American Visceral Leishmaniasis in Tocantins State, Brazil : factors associated with the occurrence and spreading of the vector Lutzomyia (Lutzomyia) longipalpis (Lutz \& Neiva, 1912) (Diptera: Psychodidae: Phlebotominae). In: Claborn D, editor. The Epidemiology and Ecology of Leishmaniasis. Missouri: InTech; 2017. p. 91-115.

41. Guerra-Silveira F, Abad-Franch F. Sex Bias in Infectious Disease Epidemiology: Patterns and Processes. PLoS One. 2013;8(4):e62390.

42. de Albuquerque LCP, Mendonça IR, Cardoso PN, Baldaçara LR, Borges MRMM, Borges JC, et al. HIV/AIDS-related visceral leishmaniasis: a clinical and epidemiological description of visceral leishmaniasis in northern Brazil. Rev Soc Bras Med Trop. 2014;47(1):38-46.

43. Hurissa Z, Gebre-Silassie S, Hailu W, Tefera T, Lalloo DG, Cuevas LE, et al. Clinical characteristics and treatment outcome of patients with visceral leishmaniasis and HIV co-infection in northwest Ethiopia. Trop Med Int Health. 2010;15(7):848-55.

44. Nascimento ET, Moura MLN, Queiroz JW, Barroso AW, Araujo AF, Rego EF, et al. The emergence of concurrent HIV-1/AIDS and visceral leishmaniasis in Northeast Brazil. Trans R Soc Trop Med Hyg. 2011;105(5):298-300.

45. World Health Organization (WHO). Control of the leishmaniases: report of a meetting of the WHO Expert Committee on the Control of Leishmaniases. 1st ed. World Health Organization Technical Report Series 949. Geneva: WHO; 2010. 202 p.

46. Organización Mundial de la Salud. Plan de acción para fortalecer la vigilancia y control de las leishmaniasis en las Américas 2017-2022. Available from: http://www2.paho.org. 2017. 70 p.

47. Maia-Elkhoury ANS, Carmo EH, Sousa-Gomes ML, Mota E. Análise dos registros de leishmaniose visceral pelo método de captura-recaptura. Rev Saude Publica. 2007;41(6):931-7.

48. Okwor I, Uzonna JE. The immunology of Leishmania/HIV coinfection. Immunol Res. 2013;56(1):163-71.

49. Ministério da Saúde (MS). Manual de recomendações para diagnóstico, tratamento e acompanhamento de pacientes com a coinfecção Leishmania-HIV. Brasilia: MS; 2011. p. 16-19.

50. Alvar J, Aparicio P, Aseffa A, Den Boer M, Cañavate C, Dedet JP, et al. The relationship between leishmaniasis and AIDS: The second 10 years. Clin Microbiol Rev. 2008;21(2):334-59.

51. Guerra JAO, Barros MLB, Ferreira Fí N, Guerra MVF, Castellon E, Gomes Paes M, et al. Leishmaniose visceral entre índios no Estado de Roraima, Brasil. Aspectos clinico epidemiológicos de casos observados no período de 1989 a 1993. Rev Soc Bras Med Trop. 2004;37(4):305-11.

52. Van den Bogaart E, Berkhout MMZ, Adams ER, Mens PF, Sentongo E, Mbulamberi DB, et al. Prevalence, features and risk factors for malaria co-infections amongst visceral leishmaniasis patients from Amudat hospital, Uganda. PLoS Negl Trop Dis. 2012;6(4):e1617. 